\title{
Synthesis and Reactivity of a Bis-Strained Alkyne Derived from 1,1'- Biphenyl-2,2',6,6'-tetrol
}

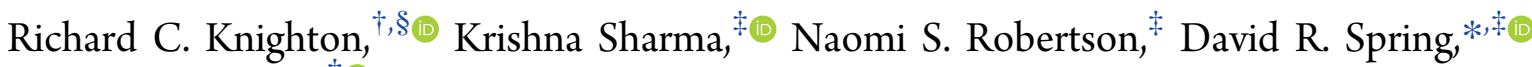 \\ and Martin Wills*, ${ }^{\dagger}$ \\ ${ }^{\dagger}$ Department of Chemistry, University of Warwick, Gibbet Hill Road, Coventry CV4 7AL, U.K. \\ ${ }^{\ddagger}$ Department of Chemistry, University of Cambridge, Lensfield Road, Cambridge CB2 1EW, U.K.
}

\section{Supporting Information}

ABSTRACT: The novel "double strained alkyne" 3 has been prepared and evaluated in strain-promoted azide-alkyne cycloaddition reactions with azides. The X-ray crystallographic structure of 3 , which was prepared in one step from $1,1^{\prime}$ biphenyl-2,2',6,6'-tetrol 4, reveals the strained nature of the alkynes. Dialkyne 3 undergoes cycloaddition reactions with a number of azides, giving mixtures of regiosiomeric products in

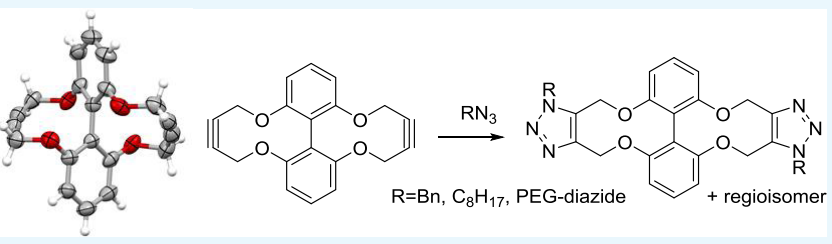
excellent yields. The monoaddition products were not observed or isolated from the reactions, suggesting that the second cycloaddition proceeds at a faster rate than the first, and this is supported by molecular modeling studies. Dialkyne 3 was successfully employed for "peptide stapling" of a p53-based diazido peptide, whereby two azides are bridged to give a product with a stabilized conformation.

\section{INTRODUCTION}

Strained alkynes, i.e., alkynes distorted from the ideal linear geometry, undergo cycloaddition reactions with azides without the requirement for a copper catalyst (Scheme 1), in processes

Scheme 1. Cycloaddition of a Strained Alkyne with an Azide

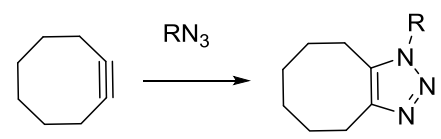

commonly referred to as strain-promoted azide-alkyne cycloaddition or "click" reactions. ${ }^{1}$ As such, their reactions are clean and require minimal processing during a workup. Moreover, due to their bioorthogonal nature, strained alkynes have established themselves as valuable reagents for bioconjugation reactions, ${ }^{2}$ for example, the attachment of fluorescent groups to proteins to track the protein's movement during biological processes. Important examples of strained alkynes that have become commercially available are shown in Figure $1 .^{3}$

Reagents that contain two strained alkynes offer the potential to link together two azide-containing functional groups or to bridge two azides in a single molecule, which offers the potential, for example, to stabilize the conformation of a flexible molecule such as a peptide. A good example of this is the Sondheimer dialkyne $\mathbf{1}$, which contains two highly strained alkynes bridged by aromatic rings. ${ }^{4,5}$ Although $\mathbf{1}$ was first reported in 1974, it was not applied to a bioconjugation application until 2010 when Kii et al. employed it to bridge between a protein-localized halotag-azide and a fluorescent azide, resulting in successful fluorescent labeling of a protein. ${ }^{6}$ The reactions of $\mathbf{1}$ with diazo compounds and furans have been reported, and the alkyne/alkene derivative has been used in a cycloaddition with an azide. ${ }^{5}$ Dialkyne $\mathbf{1}$ has also been applied to the macrocyclization of bis-azide functionalized peptides ("peptide stapling") by Spring et al. ${ }^{7}$ It has also been applied to the control of the tetramerization of HIV-related peptides. $^{8}$

In a recent research, we $\mathrm{ea}^{9 \mathrm{a} b}$ and others ${ }^{9 \mathrm{c}}$ reported the synthesis and applications to azide cycloadditions of the strained alkyne $\mathbf{2}$ and its derivatives, which can be prepared in a short sequence from readily available starting materials. We also demonstrated that its NHS-ester derivative could be successfully attached to a protein and subsequently "clicked" with an azide. ${ }^{9}$ Inspired by dialkyne 1 and its applications, we identified the corresponding biphenol-derived dialkyne 3 for synthesis and investigation as a dual click reagent (Figure 2).

\section{RESULTS AND DISCUSSION}

The envisaged strategy of synthesizing the target bis-strained alkyne 3, a modification of the previously reported monoalkynes, ${ }^{9}$ required the prior synthesis of the previously reported tetrahydroxy biphenyl precursor 4 (Scheme 2). ${ }^{10} 1,3$ Dimethoxybenzene was reacted with 1,3-dimethoxy-2-iodobenzene under $\mathrm{Cu}(\mathrm{I})$ catalysis in ethereal pyridine, giving $2,2^{\prime}, 6,6^{\prime}$-tetramethoxy-1,1'-biphenyl 5 in high yield (93\%). The methyl-protecting groups were cleaved using $\mathrm{BBr}_{3}$ in $\mathrm{CH}_{2} \mathrm{Cl}_{2}$ to obtain $1,1^{\prime}$-biphenyl-2,2',6,6'-tetrol 4 in multigram quantities (55\%). The bis-macrocyclization of the tetrol 4 was accomplished using ditosylate 6 in anhydrous $\mathrm{MeCN}$ using

Received: January 2, 2019

Accepted: January 10, 2019

Published: January 29, 2019 


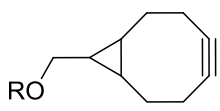

$\mathrm{BCN}$<smiles>OC1Cc2ccccc2C#Cc2ccccc21</smiles>

DIBO<smiles>[R]C(=O)N1Cc2ccccc2C=Cc2ccccc21</smiles>

DIBAC

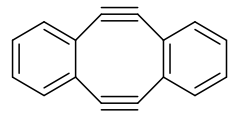

Sondheimer dialkyne 1

Figure 1. Well-established strained alkynes and dialkyne $\mathbf{1 .}$

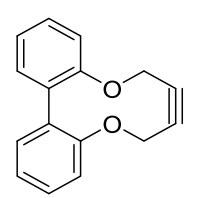

2 (previously reported)

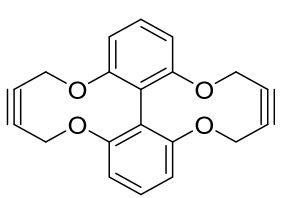

3 (reported here)

Figure 2. Known alkyne 2 and target bis-strained alkyne 3.

Scheme 2. Synthesis of Target Bis-Strained Alkyne 3

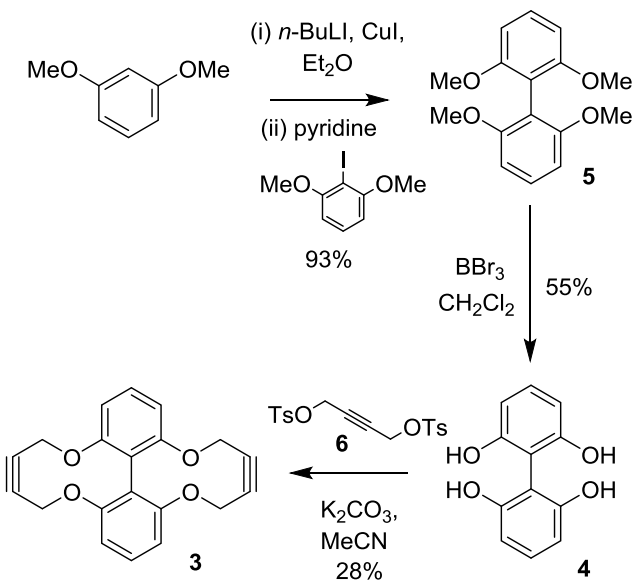

$\mathrm{K}_{2} \mathrm{CO}_{3}$ under high-dilution conditions (ca. $14 \mathrm{mM}$ ) to furnish 3 in reasonable yield (28\%) for the challenging cyclization reaction. ${ }^{9 a}$ It was found that changing the concentration or using a syringe pump to combine the reagents ${ }^{9 \mathrm{c}}$ did not improve the yield.

Crystals of $\mathbf{3}$ were obtained, which were suitable for analysis by single-crystal X-ray diffraction (Figure 3; see the Supporting

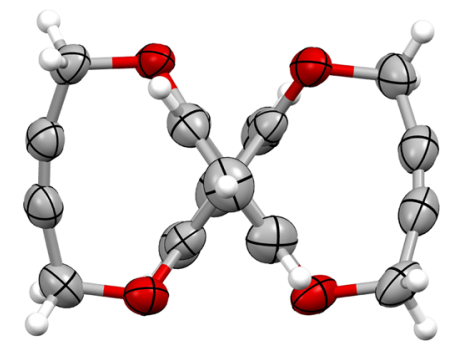

Figure 3. Single-crystal X-ray structure of bis-strained alkyne 3 (ellipsoids plotted at the $50 \%$ probability level).

Information for full details). The solution confirmed the bisstrained topology with a biphenyl (C5-C6-C7-C8) dihedral angle of $69.8(3)^{\circ}$ and an average sp bond angle of $165.3^{\circ}$. The alkynyl moieties thus exhibit a similar degree of distortion compared with the analogous monocyclic alkynes that have been studied in the solid state (sp angles typically in the range

of $\left.163.0-167.7^{\circ}\right),{ }^{9}$ indicating that $\mathbf{1}$ would be expected to have a similar reactivity.

Cycloaddition Reactions. Following the synthesis and characterization of novel bis-strained alkyne 3 , cycloaddition reactions with $\mathrm{RN}_{3}\left(\mathrm{R}=-\mathrm{CH}_{2} \mathrm{Ph}\right.$, -octyl) were undertaken to assess the efficacy of triazole formation (Scheme 3 ). The

\section{Scheme 3. Synthesis of Bis-Triazoles 7 and 8}

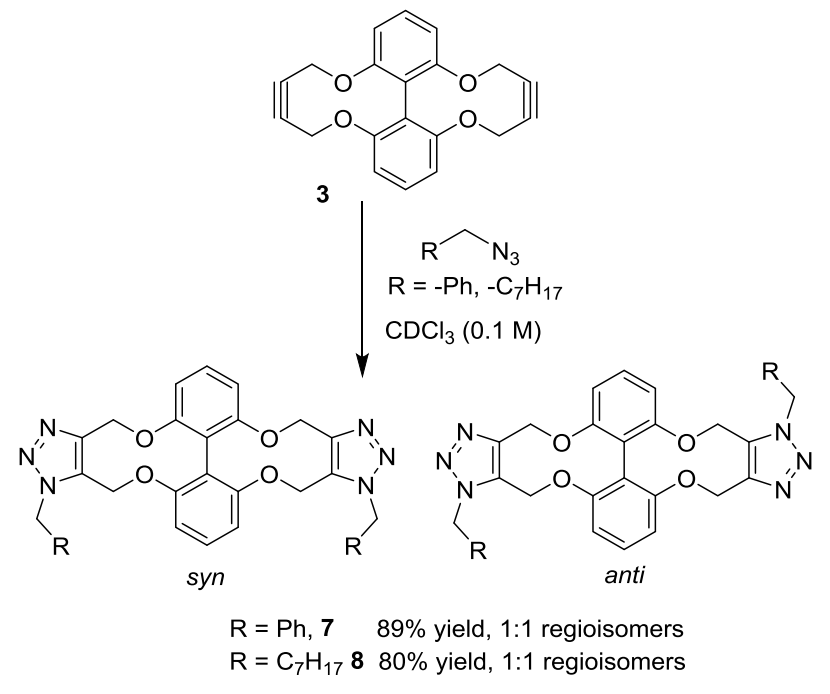

reactions were conducted in $\mathrm{CDCl}_{3}(0.1 \mathrm{M}, 298 \mathrm{~K})$ and monitored by ${ }^{1} \mathrm{H}$ NMR spectroscopy (Figure 4 illustrates the spectra for the addition of octyl azide to give 7; details of assignments are given in the Supporting Information). Both cycloaddition reactions were found to proceed with greater than $90 \%$ conversion to the bis-addition products after $72 \mathrm{~h}(\mathrm{R}$ $=-\mathrm{CH}_{2} \mathrm{Ph} ; 93.2 \%$, -octyl; 95.6\%), comparing favorably with previously reported monoalkynes based on 2 . This indicates that although bis-alkyne 3 displays a degree of alkyne sp bond strain, in the solid state, similar to previously reported monoalkynes based on 2 , it exhibits enhanced reactivity. Unexpectedly, the bis-clicked products appeared to be formed directly, with only a transient observation of what might be the intermediate monoclick product (resonance ca $\delta 4.75$ at ca. 6 and $24 \mathrm{~h}$, Figure 4), suggesting that the first addition is the rate-determining step. A similar observation was made in studies on dialkyne 1, speculated to be the result of increased steric hindrance effects. ${ }^{6}$ Alternatively, an electronic effect caused by the oxygen atoms in the ring of the initial addition product could be influencing the reaction, making the level of strain higher in the monocyclization adduct relative to that in 3 and hence the rate of the second cycloaddition step higher than that of the first. Due to the nature of the double addition reaction, it was not possible to accurately measure the rates of each step of the cycloaddition; however, in terms of conversion over time, the apparent rate constant is similar to that measured for the monocyclic derivatives of 3 , i.e., in the order 

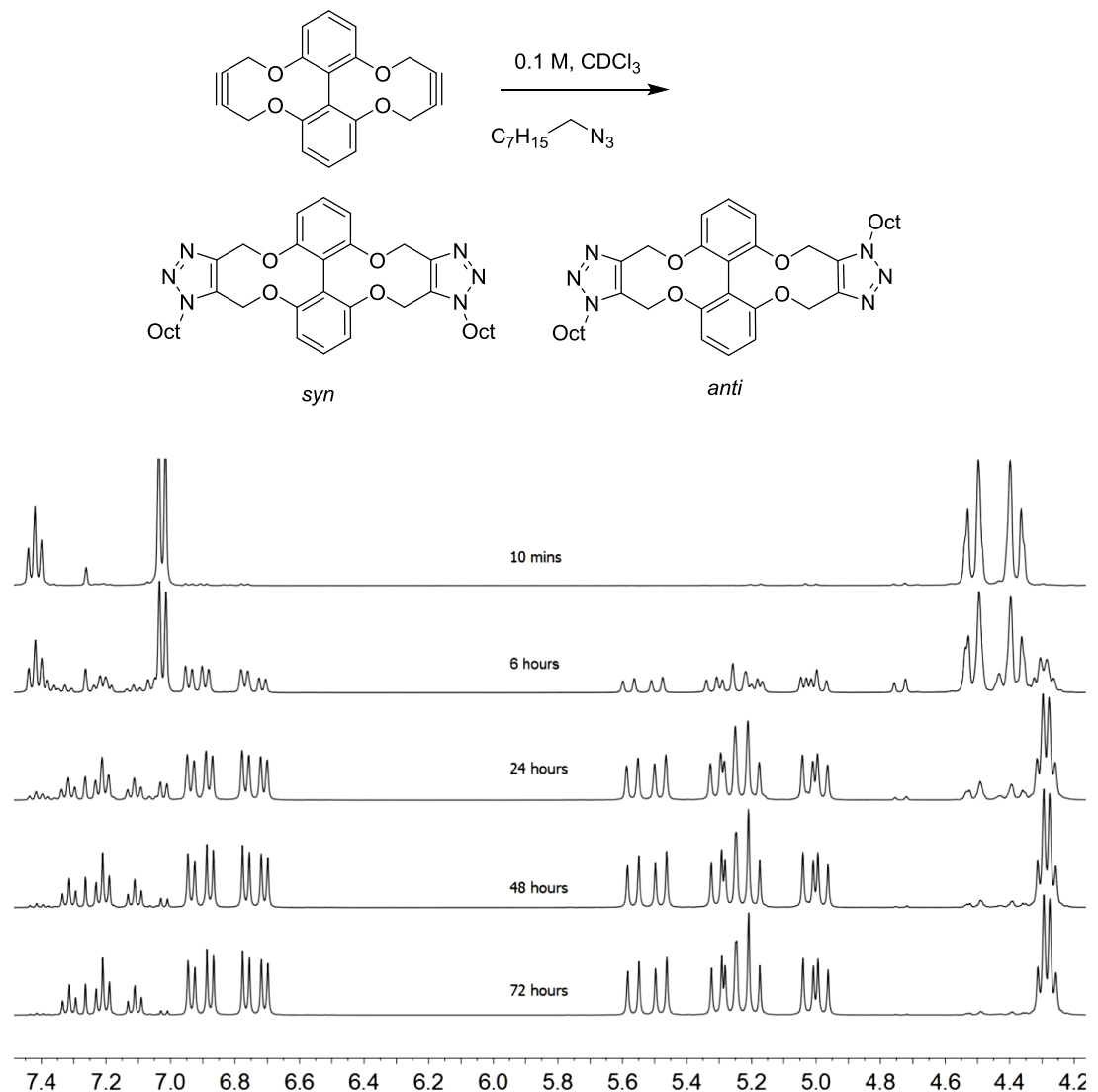

Figure 4. ${ }^{1} \mathrm{H}$ NMR $\left(400 \mathrm{MHz}, 298 \mathrm{~K}, \mathrm{CDCl}_{3}\right)$ azide-alkyne cycloaddition of 3 with 2.0 equiv of octyl azide. The doublet at ca. $\delta 4.75$ may correspond to transient formation of the monoadduct.

of $10^{-4} \mathrm{M}^{-1} \mathrm{~s}^{-1}$. Following chromatographic purification, compounds 7 and 8 were isolated in high yield $\left(\mathrm{R}=-\mathrm{CH}_{2} \mathrm{Ph}\right.$; $89 \%$, -octyl; $80 \%)$ as an inseparable $1: 1 \mathrm{mix}$ of syn- and antiregioisomers (Scheme 3). Although inseparable, it was possible to assign the signals of many of the protons in each regioisomer (see the Supporting Information).

The ${ }^{1} \mathrm{H}$ NMR spectrum of 7 in $\mathrm{CDCl}_{3}$ only indicated formation of the syn isomer due to the low solubility of anti-7. The solubility of both isomers in $\left(\mathrm{CD}_{3}\right)_{2} \mathrm{SO}$ confirms the expected 1:1 mix of regioisomers. See the Supporting Information for full details. Single crystals of compound anti7 were obtained, which were analyzed by X-ray diffraction, and the structure confirmed that the compound preferentially crystallized exclusively as the anti-isomer but as a racemic mixture of enantiomers (Figure 5; see the Supporting Information for full detail). The solution of 7 exhibits a significant diminution of biphenyl torsion compared with the parent bis-alkyne 3 ([C5-C6-C7-C8]: 7; 60.6, $3 ; 110.2^{\circ}$ for the comparable angle), reflecting the less strained topology granted by the formed $\mathrm{sp}^{2}$ triazole.

In addition, we investigated the cycloaddition reaction of a PEG-1000 diazide with 3, with the potential for formation of an addition polymer. Due to the large molecular mass of the PEG-1000, this was carried out with higher dilution than for the small molecule azides. However, a successful double-click reaction was observed, and the product was characterized by gel permeation chromatography (GPC), with full details given in the Supporting Information.

Computational Studies of the Cycloaddition. To understand the kinetics of the cycloaddition more clearly,

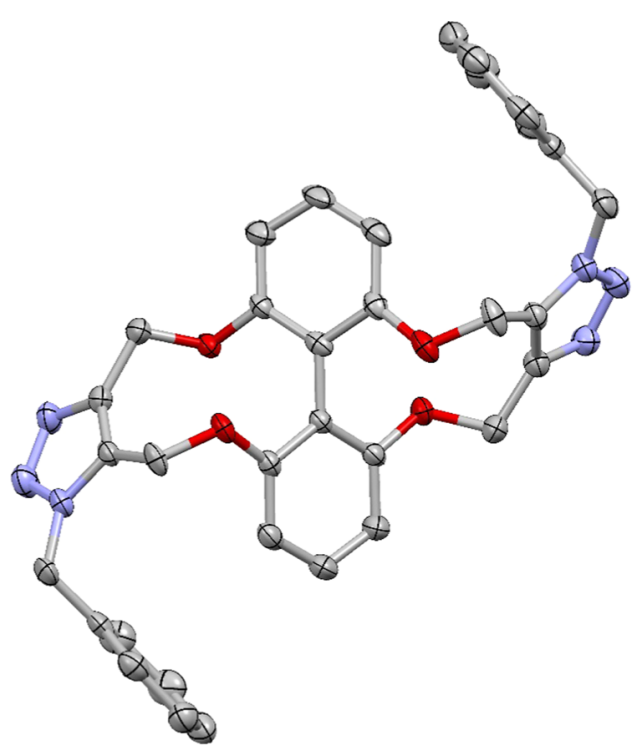

Figure 5. Single-crystal X-ray structure of anti-7 (ellipsoids plotted at the $50 \%$ probability level, $\mathrm{H}$-atoms and solvate omitted for clarity).

some molecular modeling studies were carried out using Gaussian $09^{14}$ with the B3LYP density functional and the 6$31 \mathrm{G}(\mathrm{d})$ basis set within the CPCM model at standard conditions (see the Supporting Information for full computational details). ${ }^{11,6}$ The first cycloaddition, leading to the formation of the monotriazole intermediate 9 , was found to be the rate-determining step as the results indicated that the second cycloaddition reaction, to both the syn and anti 


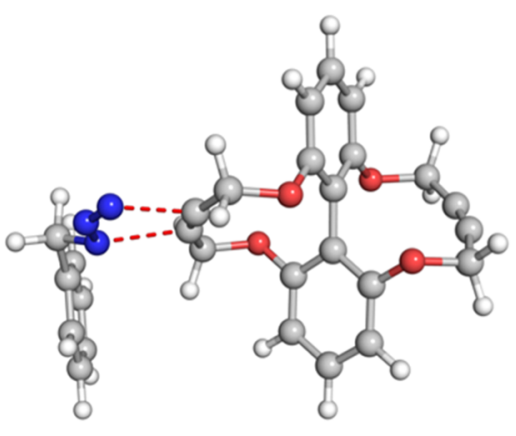

T1. $\Delta \mathrm{G}^{\ddagger}=26.1$

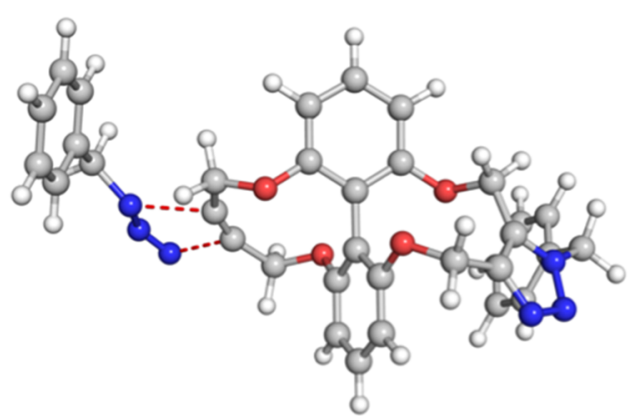

syn

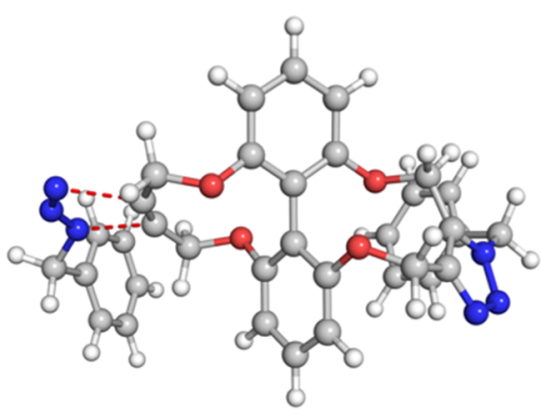

anti

T3. $\Delta \mathrm{G}^{\ddagger}=25.1$

Figure 6. Transition-state structures and activation free energies in kcal/mol for first (T1) and second cycloaddition (T2 for syn-regioisomer, T3 for anti-regioisomer) of dialkyne 3 with benzyl azide in methanol.
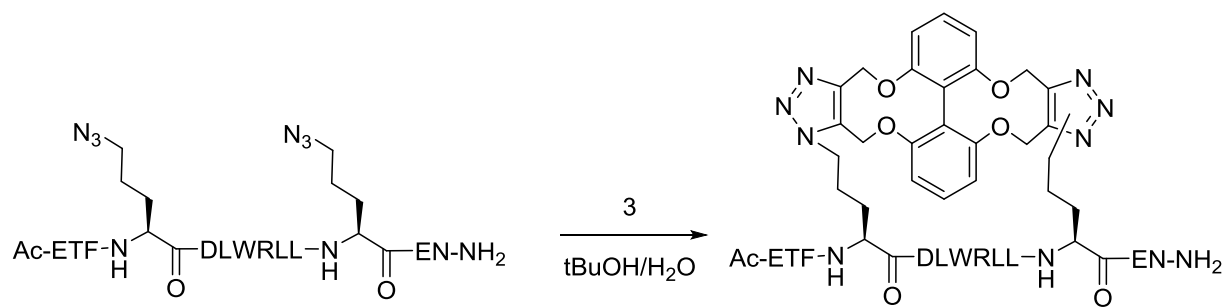

Figure 7. Peptide stapling of Ac-ETFOrn $\left(\mathrm{N}_{3}\right)$ DLWRLLOrn $\left(\mathrm{N}_{3}\right) \mathrm{EN}-\mathrm{NH}_{2}$ using 3 . The regiochemistry of the product has not been unambiguously established.

products, required a lower energy barrier than the first by $0.8-$ $1.0 \mathrm{kcal} / \mathrm{mol}$ (Figure 6; full details are given in the Supporting Information). These results mirror the experimental observations and also those reported previously for dialkyne $\mathbf{1}$, for which a specific steric interaction was suggested to be responsible. ${ }^{6}$ It is likely that a similar phenomenon is operating here, with the extra steric demands of the newly generated triazole creating additional strain energy at the remaining alkyne. This is supported by the molecular modeling studies; the alkyne bond angle for the biphenyl diyne was calculated to be $164.6^{\circ}$ (which correlates well with the average of $165.3^{\circ}$ measured in the solid state), whereas the angles for the monotriazole intermediate were 162.4 and $162.5^{\circ}$, respectively.

Peptide Stapling Studies. Given the promising results described above, some investigations were carried out into the use of $\mathbf{3}$ as a reagent for peptide stapling, a process in which a flexible linear peptide can be "fixed" into a much more stable conformation by linking two groups in the chain (Figure 7). ${ }^{7,12}$ A ${ }^{(17-29)}$ p53 peptide (Ac-ETFOrn $\left(\mathrm{N}_{3}\right)$ DLWRLLOrn $\left(\mathrm{N}_{3}\right)$ EN$\mathrm{NH}_{2}$ ) was studied. Purified peptide and bis-alkyne 3 (1.1 equiv) were combined in ${ }^{t} \mathrm{BuOH} / \mathrm{H}_{2} \mathrm{O}$. The resulting solution ([peptide] $=$ ca. $0.6 \mathrm{mM}$ ) was stirred at room temperature for $72 \mathrm{~h}$. After $24 \mathrm{~h}$ at room temperature, a small amount of stapling was observed by ESI-mass spectrometry (ESI-MS). The stapled peptide product (MW: 2075.28) coelutes with the LCMS peak of the starting material (MW: 1756.95) (Supporting Information). We attempted the reaction over $24 \mathrm{~h}$ at $\mathrm{rt}$ followed by $24 \mathrm{~h}$ at $37{ }^{\circ} \mathrm{C}$, but the reaction did not reach completion. At $48 \mathrm{~h}$, another 1.5 equiv of linker was added, while maintaining the reaction stirring at $37{ }^{\circ} \mathrm{C}$. Maintaining the temperature at $37{ }^{\circ} \mathrm{C}$ gave better results; however, conversion to the stapled peptide was incomplete and some starting material was still observed after $72 \mathrm{~h}$ (full details are in the Supporting Information). These results indicate that although 3 is less reactive than dialkyne $1,^{6-8}$ it has the potential to be used successfully as a "peptide stapling" reagent and will react even at the low concentrations required for this type of reaction. To confirm that both azides on the peptide had reacted, IR spectra were recorded; the disappearance of the azide stretch at $2097 \mathrm{~cm}^{-1}$ was observed (Supporting Information). The increased reactivity of the second cycloaddition, coupled to its intramolecular nature, is likely to be facilitating the ring-closure process. It is likely that a mixture of syn- and anti-regioisomers was formed (see the Supporting information).

\section{CONCLUSIONS}

In summary, we have reported the synthesis of a novel bisstrained alkyne compound 3 in three steps from readily available commercial reagents. Dialkyne 3 was demonstrated to be capable of cycloaddition reactions with azides in high conversion $(>90 \%)$ without the requirement for the use of a catalyst. The rate of the cycloadditions with 3 was significantly lower than with diyne $\mathbf{1}$, for which double cycloadditions are reported to be complete within $1-4 \mathrm{~h}$ at $\mathrm{rt}^{6,7}$ (the rate constant has been measured as $(6.29 \pm 0.05) \times 10^{-2} \mathrm{M}^{-1} \mathrm{~s}^{-1}$ in $\mathrm{MeOH}$ at $\left.25^{\circ} \mathrm{C}\right){ }^{6} \mathrm{X}$-ray crystallographic studies of 3 and anti-7 reveal the decrease in strain upon cycloaddition of azide, the main driving force for the reaction. Computational studies supported the experimental observation of a slower first cycloaddition, representing the rate-determining step. The new bis-strained alkyne 3 has been used in preliminary stapling experiments, demonstrating its potential applications to this application. Although again $\mathbf{3}$ is less reactive than diyne $\mathbf{1}$ in this application, an excess of dialkyne 3 was required, with warming, whereas an analogous peptide stapling reaction with 1.1 equiv of 1 was reported to be complete within $16 \mathrm{~h}$ at $\mathrm{rt}^{7 \mathrm{a}}$ However, reagent 3 also reacts without the need for a copper 
catalyst and can therefore deliver clean products without the requirement to remove metal residues, which is the principle advantage of strained alkynes over unstrained ones. Furthermore, it can be prepared in one synthetic step from a readily available starting material. In situations where the highest reaction rates are not required, this potentially makes it a synthetically valuable alternative to 1 . Studies continue to define the scope of this reagent and to isolate and study the properties of the stapled peptide.

\section{EXPERIMENTAL SECTION}

Compounds $\mathbf{4}$ and $\mathbf{5}$ were prepared as previously described following the published methods and their spectra matched those reported. ${ }^{10}$ General experimental details, conversion/ time graphs and related spectra, and GPC details are given in the Supporting Information.

General Experimental Details. All solvents and reagents were degassed before use and all reactions were carried out under a nitrogen atmosphere. Reactions were monitored by thin-layer chromatography using aluminum-backed silica gel 60 (F254) plates, visualized using UV $254 \mathrm{~nm}$ and phosphomolybdic acid or potassium permanganate dips as appropriate. Flash column chromatography was carried out routinely on silica gel. Reagents were used as received from commercial sources unless otherwise stated. Copper(I) iodide was dried at $120{ }^{\circ} \mathrm{C}$ for $18 \mathrm{~h}$ under dynamic vacuum and stored under $\mathrm{N}_{2}$, protected from light. Dry solvents were purchased and used as received. ${ }^{1} \mathrm{H}$ NMR spectra were recorded on a Bruker DPX $(400$ or $500 \mathrm{MHz}$ ) spectrometer. Chemical shifts are reported in $\delta$ units, parts per million relative to the singlet at $7.26 \mathrm{ppm}$ for chloroform and $0.00 \mathrm{ppm}$ for tetramethylsilane. Mass spectra were recorded on a Bruker Esquire2000 ESI or a Bruker MicroTOF mass spectrometer. Coupling constants $(J)$ are measured in hertz. IR spectra were recorded on a

PerkinElmer Spectrum One FT-IR Golden Gate. Melting points were recorded on a Stuart Scientific SMP 1 instrument and are uncorrected.

Synthesis of Bis-Alkyne 3.<smiles>C#CCOc1cccc(OC)c1C1=C2C=CC=C(OCC#CCO2)OCC#C1</smiles>

1,1'-Biphenyl-2,2',6,6' -tetrol (150 mg, $0.687 \mathrm{mmol})$ was added to but-2-ene ditosylate $(568 \mathrm{mg}, 1.44 \mathrm{mmol})$ and $\mathrm{K}_{2} \mathrm{CO}_{3}(474$ $\mathrm{mg}, 3.43 \mathrm{mmol})$ in acetonitrile $(50 \mathrm{~mL}$, ca. $14 \mathrm{mM})$, and the mixture was stirred at ambient temperature for 19 days. The solvent was removed under reduced pressure, followed by addition of $\mathrm{H}_{2} \mathrm{O}(30 \mathrm{~mL})$, extraction with $\mathrm{CH}_{2} \mathrm{Cl}_{2}(3 \times 30$ $\mathrm{mL})$, and drying $\left(\mathrm{MgSO}_{4}\right)$. Removal of the solvent under reduced pressure gave yellow oil, which was subsequently purified by silica gel column chromatography (EtOAc/hexane 20:80 $\rightarrow$ 40:60) to afford a white solid. This crude solid was recrystallized from hot $\mathrm{EtOH}$, which was subsequently cooled to $4{ }^{\circ} \mathrm{C}$, filtered, and washed with ice cold $\mathrm{EtOH}$ to afford white X-ray diffraction quality crystals of the title compound as a racemic mixture $(60 \mathrm{mg}, 0.18 \mathrm{mmol}, 28 \%) . \mathrm{Mp} 222-230^{\circ} \mathrm{C}$ (dec); (found (ESI): $[\mathrm{M}+\mathrm{Na}]^{+}, 341.0786 . \mathrm{C}_{20} \mathrm{H}_{14} \mathrm{O}_{4}^{+}$ requires $\left.[\mathrm{M}+\mathrm{Na}]^{+}, 341.0784\right) ; \nu_{\max } 2938,2885,1549,1061$ and $831 \mathrm{~cm}^{-1} ; \delta_{\mathrm{H}}\left(500 \mathrm{MHz}, \mathrm{CDCl}_{3}\right) 7.43(2 \mathrm{H}, \mathrm{t}, J 8.1, \mathrm{ArH})$, $7.03(4 \mathrm{H}, \mathrm{d}, J$ 8.1, $\mathrm{ArH}), 4.58-4.46\left(4 \mathrm{H}, \mathrm{m}, \mathrm{OCH}_{2}\right), 4.43-$ $4.33\left(4 \mathrm{H}, \mathrm{m}, \mathrm{OCH}_{2}\right) ; \delta_{\mathrm{C}}\left(126 \mathrm{MHz}, \mathrm{CDCl}_{3}\right) 156.08(\mathrm{ArO})$, $130.01(\mathrm{ArH}), 128.67$ (ArC), $118.54(\mathrm{ArH}), 87.12(\mathrm{CC})$, $63.56\left(\mathrm{OCH}_{2}\right) ; m / z(\mathrm{ESI}) 341\left(\mathrm{M}^{+}+\mathrm{Na}, 100 \%\right)$ and 659 $\left(2 \mathrm{M}^{+}+\mathrm{Na}, 100\right)$.
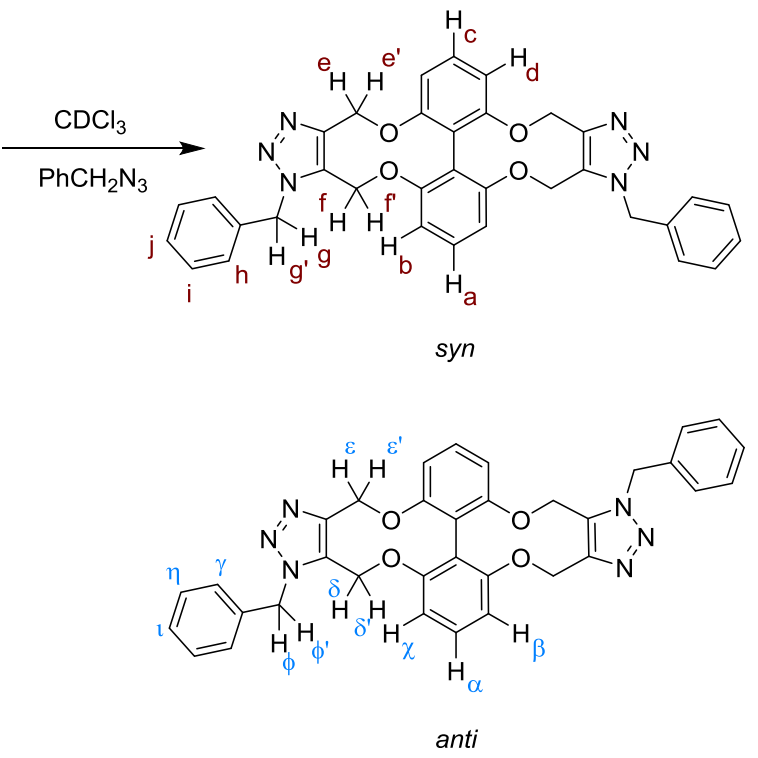

Synthesis of Bis-Benzyl Triazole 7.A solution of $3(15.9 \mathrm{mg}$, $0.05 \mathrm{mmol}$ ) and benzyl azide $(13.3 \mathrm{mg}, 0.10 \mathrm{mmol})$ in $\mathrm{CDCl}_{3}$ $(0.5 \mathrm{~mL}, 100 \mathrm{mM})$ was prepared with a J. Young's NMR tube. In situ analysis by NMR spectroscopy indicated formation of the desired bis-triazole compounds within $72 \mathrm{~h}$ at ambient temperature. After 5 days, the solvent was removed in vacuo and purified by column chromatography $\left(\mathrm{SiO}_{2} ; \mathrm{EtOAc} /\right.$ hexane; 20:80 $\rightarrow$ 50:50) to obtain a 1:1 mixture of regioisomers as a white solid (26 $\mathrm{mg}, 0.044 \mathrm{mmol}, 89 \%$ ). Note: Due to the insolubility of anti-regioisomer in $\mathrm{CDCl}_{3}$ (this crystallizes from solution and the provided material for the X-ray crystal structure given below), the NMR data is given only for the syn isomer. However, both syn- and anti-isomers are soluble and observable in $\left(\mathrm{CD}_{3}\right)_{2} \mathrm{SO}$. Mp $140-143{ }^{\circ} \mathrm{C}$; (found (ESI): $[\mathrm{M}+\mathrm{Na}]^{+}, 607.2068, \mathrm{C}_{34} \mathrm{H}_{28} \mathrm{~N}_{6} \mathrm{O}_{4}{ }^{+}$requires $\left.[\mathrm{M}+\mathrm{Na}]^{+}, 607.2064\right) ; \nu_{\max } 1590,1573,1451,1071,704$ and 
$671 \mathrm{~cm}^{-1} ; \delta_{\mathrm{H}}\left(600 \mathrm{MHz}, \mathrm{CDCl}_{3}\right) 7.34\left(6 \mathrm{H}, \mathrm{m}, \mathrm{ArH}, \mathrm{H}^{\mathrm{i}}\right.$ and $\left.\mathrm{H}^{\mathrm{j}}\right), 7.18\left(1 \mathrm{H}, \mathrm{t}, J\right.$ 8.2, $\left.\mathrm{ArH}, \mathrm{H}^{\mathrm{a} / \mathrm{c}}\right), 7.17-7.13(4 \mathrm{H}, \mathrm{m}, \mathrm{ArH}$, $\left.\mathrm{H}^{\mathrm{H}}\right), 6.98\left(1 \mathrm{H}, \mathrm{t}, J\right.$ 8.2, $\left.\mathrm{ArH}, \mathrm{H}^{\mathrm{a} / \mathrm{c}}\right), 6.82(2 \mathrm{H}, \mathrm{d}, J$ 8.3, $\mathrm{ArH}$, $\left.\mathrm{H}^{\mathrm{b} / \mathrm{d}}\right), 6.44\left(2 \mathrm{H}, \mathrm{d}, J\right.$ 8.4, $\left.\operatorname{ArH}, \mathrm{H}^{\mathrm{b} / \mathrm{d}}\right), 5.71(2 \mathrm{H}, \mathrm{d}, J$ 15.7, $\left.\mathrm{OCH}_{2}, \mathrm{H}^{\mathrm{g} / \mathrm{g} /}\right), 5.41\left(2 \mathrm{H}, \mathrm{d}, J 13.5, \mathrm{OCH}_{2}, \mathrm{H}^{\mathrm{e} / \mathrm{f}}\right), 5.37(2 \mathrm{H}, \mathrm{d}, J$ 15.6, $\left.\mathrm{OCH}_{2}, \mathrm{H}^{\mathrm{g} / \mathrm{g} \prime}\right), 5.27\left(2 \mathrm{H}, \mathrm{d}, J 13.5, \mathrm{OCH}_{2}, \mathrm{H}^{\mathrm{e} / \mathrm{ff}}\right), 5.14$ $\left(2 \mathrm{H}, \mathrm{d}, J\right.$ 13.3, $\left.\mathrm{OCH}_{2}, \mathrm{H}^{\mathrm{e} / \mathrm{f}}\right), 4.98\left(2 \mathrm{H}, \mathrm{d}, J\right.$ 13.4, $\mathrm{OCH}_{2}$, $\left.\mathrm{H}^{\mathrm{e} / \mathrm{f} \prime}\right) ; \delta_{\mathrm{H}}\left(500 \mathrm{MHz},\left(\mathrm{CD}_{3}\right)_{2} \mathrm{SO}\right) 7.40-7.33(12 \mathrm{H}, \mathrm{m}, \mathrm{ArH}$, $\mathrm{H}^{\mathrm{i}}, \mathrm{H}^{\mathrm{i}}, \mathrm{H}^{\eta}$, and $\left.\mathrm{H}^{\tau}\right), 7.29-7.26\left(9 \mathrm{H}, \mathrm{m}, \mathrm{ArH}, \mathrm{H}^{\mathrm{H}}, \mathrm{H}^{\gamma}\right.$, and $\left.\mathrm{H}^{\mathrm{a} / \mathrm{c}}\right), 7.05\left(2 \mathrm{H}, \mathrm{t}, J\right.$ 8.2, $\left.\mathrm{ArH}, \mathrm{H}^{\alpha}\right), 6.92(2 \mathrm{H}, \mathrm{d}, J$ 8.2, $\mathrm{ArH}$, $\left.\mathrm{H}^{\mathrm{b} / \mathrm{d}}\right), 6.86\left(3 \mathrm{H}, \mathrm{m}, \mathrm{ArH}, \mathrm{H}^{\beta / \chi}\right.$ and $\left.\mathrm{H}^{\mathrm{a} / \mathrm{c}}\right), 6.64(4 \mathrm{H}$, app. $\mathrm{t}, J$ $8.8, \mathrm{H}^{\mathrm{b} / \mathrm{d}}$ and $\left.\mathrm{H}^{\beta / \chi}\right), 5.76\left(4 \mathrm{H}, \mathrm{dd}, J 15.6,2.6, \mathrm{OCH}_{2}, \mathrm{H}^{\mathrm{f} / \mathrm{e}}\right.$ or $\left.\mathrm{H}^{\delta / \varepsilon}\right), 5.67\left(4 \mathrm{H}, \mathrm{d}, J 15.5, \mathrm{OCH}_{2}, \mathrm{H}^{\mathrm{f} / / \mathrm{e} \prime}\right.$ or $\left.\mathrm{H}^{\delta \prime / \varepsilon \prime}\right), 5.45(4 \mathrm{H}$, dd, J 14.4, 2.3, $\mathrm{OCH}_{2}, \mathrm{H}^{\mathrm{f} / \mathrm{e}}$ or $\left.\mathrm{H}^{\delta / \varepsilon}\right), 5.41-5.30\left(8 \mathrm{H}, \mathrm{m}, \mathrm{OCH}_{2}\right.$ and $\mathrm{ArCH}_{2}, \mathrm{H}^{\mathrm{f} / / \mathrm{e} \prime}$ or $\mathrm{H}^{\delta / / \varepsilon \prime}$ and $\left.\mathrm{H}^{\mathrm{g} / \varphi}\right), 5.08(2 \mathrm{H}, \mathrm{d}, J 12.4,5.8$, $\mathrm{ArCH}_{2}, \mathrm{H}^{\mathrm{f} / \mathrm{e}}$ or $\left.\mathrm{H}^{\delta / \varepsilon}\right), 5.06\left(2 \mathrm{H}, \mathrm{d}, J 12.4,5.8, \mathrm{ArCH}_{2}, \mathrm{H}^{\mathrm{f} / \mathrm{e} /}\right.$ or $\left.\mathrm{H}^{\delta \prime / \varepsilon \prime}\right) ; \delta_{\mathrm{C}}\left(151 \mathrm{MHz}, \mathrm{CDCl}_{3}\right) 157.97(\mathrm{ArO}), 156.52(\mathrm{ArO})$, $144.83(\mathrm{Tz}), 134.81\left(\mathrm{Ar}^{\mathrm{Benzyl}}\right), 132.30(\mathrm{Tz}), 129.32\left(\mathrm{Ar}^{\mathrm{Benzyl}}\right)$,
$129.13(\mathrm{ArH}), 128.74$ (ArH), $127.23\left(\mathrm{AR}^{\text {Benzyl }}\right), 127.19$ $\left(\mathrm{Ar}^{\text {Benzyl }}\right), 118.51(\mathrm{Ar}), 115.54(\mathrm{Ar}), 111.30(\mathrm{ArH}), 108.99$ $(\mathrm{ArH}), 63.33\left(\mathrm{OCH}_{2}\right), 61.12\left(\mathrm{OCH}_{2}\right), 52.52\left(\mathrm{PhCH}_{2}\right) ; \delta_{\mathrm{C}}$ $\left(126 \mathrm{MHz},\left(\mathrm{CD}_{3}\right)_{2} \mathrm{SO}\right) 158.08$ ( $\left.\mathrm{ArO}, \mathrm{C}^{\text {syn/anti }}\right), 157.97(\mathrm{ArO}$, $\left.\mathrm{C}^{\text {syn/anti }}\right), 156.33\left(\mathrm{ArO}, \mathrm{C}^{\text {syn/anti }}\right), 156.21$ (ArO, C $\left.\mathrm{C}^{\text {syn/anti}}\right)$, $143.37\left(\mathrm{Tz}, \mathrm{C}^{\text {syn/anti }}\right), 143.34\left(\mathrm{Tz}, \mathrm{C}^{\text {syn/anti }}\right), 135.66(\mathrm{Tz}$, $\left.\mathrm{C}^{\text {syn/anti }}\right), 135.63\left(\mathrm{Tz}, \mathrm{C}^{\text {syn/anti }}\right), 133.33\left(\mathrm{ArH}, \mathrm{C}^{\text {syn/anti }}\right), 128.85$ $\left(\mathrm{ArH}, \mathrm{C}^{\text {syn/anti }}\right), 128.80\left(\mathrm{ArH}, \mathrm{C}^{\text {syn/anti }}\right), 128.78\left(\mathrm{ArH}, \mathrm{C}^{\text {syn/anti }}\right)$, 128.60 (ArH, $\left.\mathrm{C}^{\text {syn/anti }}\right), 128.34\left(\mathrm{ArH}, \mathrm{C}^{\text {syn/anti }}\right), 128.14(\mathrm{ArH}$, $\left.\mathrm{C}^{\text {syn/anti }}\right), 128.12\left(\mathrm{ArH}, \mathrm{C}^{\text {syn/anti }}\right), 127.67\left(\mathrm{ArH}, \mathrm{C}^{\text {syn/anti}}\right)$, $116.94\left(\mathrm{Ar}, \mathrm{C}^{\mathrm{anti}}\right), 116.58\left(\mathrm{ArH}, \mathrm{C}^{\mathrm{anti}}\right), 116.30\left(\mathrm{ArH}, \mathrm{C}^{\text {syn }}\right)$, $111.02\left(\mathrm{ArH}, \mathrm{C}^{\text {syn/anti }}\right), 110.82\left(\mathrm{ArH}, \mathrm{C}^{\text {syn/anti}}\right), 108.47(\mathrm{ArH}$, $\left.\mathrm{C}^{\text {syn/anti }}\right), 108.36\left(\mathrm{ArH}, \mathrm{C}^{\text {syn/anti }}\right), 64.88\left(\mathrm{ArCH}_{2}, \mathrm{C}^{\text {syn/anti }}\right)$, $64.76\left(\mathrm{ArCH}_{2}, \mathrm{C}^{\text {syn/anti }}\right), 59.05\left(\mathrm{OCH}_{2}, \mathrm{C}^{\text {syn/anti }}\right), 58.93$ $\left(\mathrm{OCH}_{2}, \mathrm{C}^{\text {syn/anti }}\right), 50.95\left(\mathrm{OCH}_{2}, \mathrm{C}^{\text {syn } / \text { anti }}\right), 50.93\left(\mathrm{OCH}_{2}\right.$, $\left.\mathrm{C}^{\text {syn/anti }}\right) ; m / z$ (ESI) $585\left(\mathrm{M}^{+}+\mathrm{H}, 78 \%\right)$ and $607\left(\mathrm{M}^{+}+\mathrm{Na}\right.$, 100).
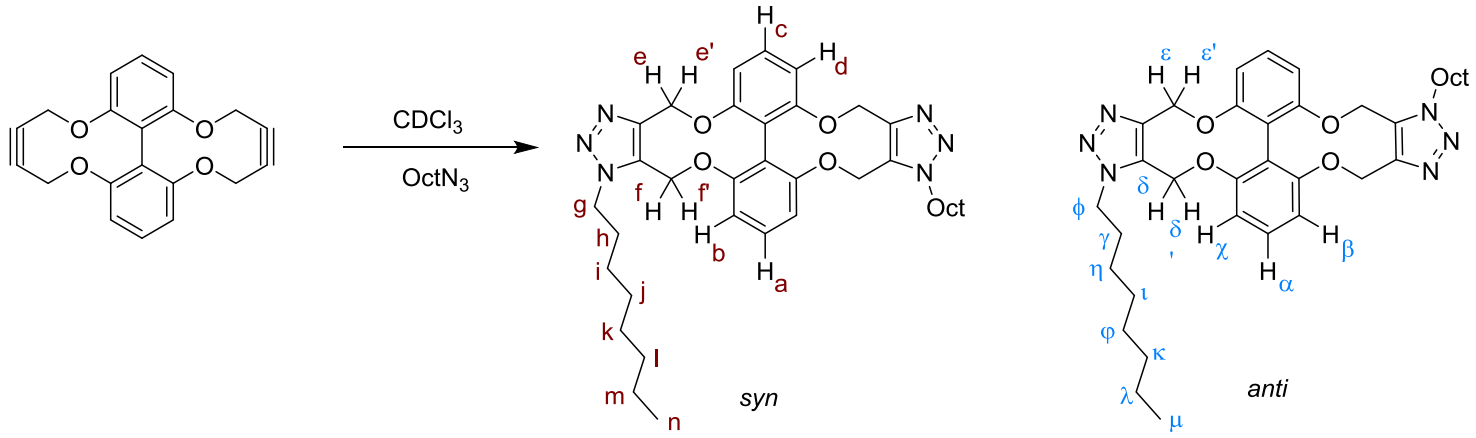

Synthesis of Bis-Octyl Trizole 8.A solution of $3(15.9 \mathrm{mg}$, $0.05 \mathrm{mmol}$ ) and benzyl azide $(15.5 \mathrm{mg}, 0.10 \mathrm{mmol})$ in $\mathrm{CDCl}_{3}$ $(0.5 \mathrm{~mL}, 100 \mathrm{mM})$ was prepared with a J. Young's NMR tube. In situ analysis by NMR spectroscopy indicated formation of the desired bis-triazole compounds within $72 \mathrm{~h}$ at room temperature. After 6 days, the solvent was removed in vacuo and purified by preparative thin-layer chromatography $\left(\mathrm{SiO}_{2}\right.$; $\mathrm{EtOAc} /$ hexane; 50:50) to obtain a 1:1 mixture of regioisomers as a white solid ( $25 \mathrm{mg}, 0.040 \mathrm{mmol}, 80 \%)$. Mp $105-107^{\circ} \mathrm{C}$; (found (ESI): $[\mathrm{M}+\mathrm{Na}]^{+}, 651.3642 . \mathrm{C}_{36} \mathrm{H}_{48} \mathrm{~N}_{6} \mathrm{O}_{4}{ }^{+}$requires $\left.[\mathrm{M}+\mathrm{Na}]^{+}, 651.3629\right) ; \nu_{\max } 2926,2855,1591,1453,1222$, 1069,777 , and $718 \mathrm{~cm}^{-1} ; \delta_{\mathrm{H}}\left(500 \mathrm{MHz}, \mathrm{CDCl}_{3}\right) 7.33(1 \mathrm{H}, \mathrm{t}, J$ 8.2, $\left.\mathrm{ArH}, \mathrm{H}^{\mathrm{a} / \mathrm{c}}\right), 7.22\left(2 \mathrm{H}, \mathrm{t}, J\right.$ 8.2, $\left.\mathrm{ArH}, \mathrm{H}^{\alpha}\right), 7.12(1 \mathrm{H}, \mathrm{t}, J$ 8.4, $\left.\mathrm{ArH}, \mathrm{H}^{\mathrm{a} / \mathrm{c}}\right), 6.95\left(2 \mathrm{H}, \mathrm{d}, J\right.$ 8.4, $\left.\operatorname{ArH}, \mathrm{H}^{\beta, \chi}\right), 6.90(2 \mathrm{H}, \mathrm{d}, J$ 8.1, $\left.\mathrm{ArH}, \mathrm{H}^{\mathrm{b} / \mathrm{d}}\right), 6.78\left(2 \mathrm{H}, \mathrm{d}, J\right.$ 8.4, $\left.\mathrm{ArH}, \mathrm{H}^{\mathrm{b} / \mathrm{d}}\right), 6.72(2 \mathrm{H}, \mathrm{d}, J$ 8.1, $\left.\mathrm{ArH}, \mathrm{H}^{\beta, \chi}\right), 5.59\left(2 \mathrm{H}, \mathrm{d}, J\right.$ 14.1, $\left.\mathrm{OCH}_{2} \mathrm{H}^{\mathrm{e} / \mathrm{f}}\right), 5.50(2 \mathrm{H}, \mathrm{d}, J$ 14.0, $\left.\mathrm{OCH}_{2}, \mathrm{H}^{\mathrm{e} / \mathrm{ff}}\right), 5.33\left(2 \mathrm{H}, \mathrm{d}, J 12.6, \mathrm{OCH}_{2}, \mathrm{H}^{\delta / \varepsilon}\right), 5.28$ $\left(2 \mathrm{H}, \mathrm{d}, J 12.6, \mathrm{OCH}_{2}, \mathrm{H}^{\delta \prime / \varepsilon \prime}\right), 5.25\left(2 \mathrm{H}, \mathrm{d}, J 14.1, \mathrm{OCH}_{2}\right.$, $\left.\mathrm{H}^{\mathrm{e} / \mathrm{f}}\right), 5.21\left(2 \mathrm{H}, \mathrm{d}, J 14.0, \mathrm{OCH}_{2}, \mathrm{H}^{\mathrm{e} / \mathrm{f} \prime}\right), 5.03(2 \mathrm{H}, \mathrm{d}, J 12.6$, $\left.\mathrm{OCH}_{2}, \mathrm{H}^{\delta / \varepsilon}\right), 4.98\left(2 \mathrm{H}, \mathrm{d}, J\right.$ 12.6, $\left.\mathrm{OCH}_{2}, \mathrm{H}^{\delta / / \varepsilon \prime}\right), 4.33-4.26$ $\left(8 \mathrm{H}, \mathrm{m}, \mathrm{TzCH}_{2}, \mathrm{H}^{\mathrm{g}}\right.$ and $\left.\mathrm{H}^{\varphi}\right), 1.88-1.78\left(8 \mathrm{H}, \mathrm{m}, \mathrm{CH}_{2}, \mathrm{H}^{\mathrm{H}}\right.$ and $\left.\mathrm{H}^{\gamma}\right), 1.28-1.18\left(40 \mathrm{H}, \mathrm{m}, \mathrm{CH}_{2}, \mathrm{H}^{\mathrm{i}-\mathrm{m}}\right.$ and $\left.\mathrm{H}^{\eta-\lambda}\right), 0.87(6 \mathrm{H}, \mathrm{t}, J$ 7.0, $\left.\mathrm{CH}_{3}, \mathrm{H}^{\mathrm{n} / \mu}\right), 0.86\left(6 \mathrm{H}, \mathrm{t}, J 7.1, \mathrm{CH}_{3}, \mathrm{H}^{\mathrm{n} / \mu}\right) ; \delta_{\mathrm{C}}(126 \mathrm{MHz}$, $\left.\mathrm{CDCl}_{3}\right)$ 158.84 ( $\left.\mathrm{ArO}, \mathrm{C}^{\text {anti }}\right), 158.74\left(\mathrm{ArO}, \mathrm{C}^{\text {syn }}\right), 155.94(\mathrm{ArO}$, $\left.\mathrm{C}^{\text {syn }}\right), 155.83\left(\mathrm{ArO}, \mathrm{C}^{\mathrm{anti}}\right), 144.43\left(\mathrm{Tz}, \mathrm{C}^{\text {syn/anti }}\right), 144.41(\mathrm{Tz}$, $\left.\mathrm{C}^{\text {syn/anti }}\right), 131.68\left(\mathrm{Tz}, \mathrm{C}^{\text {syn/anti }}\right), 131.60\left(\mathrm{Tz}, \mathrm{C}^{\text {syn/anti }}\right), 129.29$ $\left(\mathrm{Ar}, \mathrm{C}^{\text {syn }}\right), 129.23\left(\mathrm{Ar}, \mathrm{C}^{\text {anti }}\right), 129.13\left(\mathrm{Ar}, \mathrm{C}^{\text {syn }}\right), 119.58(\mathrm{Ar}$, $\left.\mathrm{C}^{\text {syn }}\right), 117.33\left(\mathrm{Ar}, \mathrm{C}^{\text {anti }}\right), 115.10\left(\mathrm{Ar}, \mathrm{C}^{\text {syn }}\right), 112.81\left(\mathrm{ArH}, \mathrm{C}^{\text {syn }}\right)$, $111.38\left(\mathrm{ArH}, \mathrm{C}^{\mathrm{anti}}\right), 109.51\left(\mathrm{ArH}, \mathrm{C}^{\text {anti }}\right), 108.14\left(\mathrm{ArH}, \mathrm{C}^{\mathrm{syn}}\right)$, $62.48\left(\mathrm{OCH}_{2}, \mathrm{C}^{\text {syn/anti }}\right), 62.32\left(\mathrm{OCH}_{2}, \mathrm{C}^{\text {syn/anti }}\right), 62.04$ $\left(\mathrm{OCH}_{2}, \mathrm{C}^{\text {syn/anti }}\right), 61.99\left(\mathrm{OCH}_{2}, \mathrm{C}^{\text {syn/anti }}\right), 48.67\left(\mathrm{TzCH}_{2}\right.$, $\left.\mathrm{C}^{\text {syn/anti }}\right), 48.63\left(\mathrm{TzCH}_{2}, \mathrm{C}^{\text {syn/anti }}\right) 31.82\left(\mathrm{CH}_{2}, \mathrm{C}^{\text {syn/anti }}\right), 31.80$
$\left(\mathrm{CH}_{2}, \mathrm{C}^{\text {syn/anti}}\right), 30.72\left(\mathrm{CH}_{2}, \mathrm{C}^{\text {syn/anti }}\right), 30.70\left(\mathrm{CH}_{2}, \mathrm{C}^{\text {syn/anti }}\right)$, $29.16\left(\mathrm{CH}_{2}, \mathrm{C}^{\text {syn } / \text { anti }}\right), 29.14\left(\mathrm{CH}_{2}, \mathrm{C}^{\text {syn/anti }}\right), 29.07\left(\mathrm{CH}_{2}\right.$, $\left.\mathrm{C}^{\text {syn/anti }}\right), 29.05\left(\mathrm{CH}_{2}, \mathrm{C}^{\text {syn/anti }}\right), 26.60\left(\mathrm{CH}_{2}, \mathrm{C}^{\text {syn/anti }}\right), 26.57$ $\left(\mathrm{CH}_{2}, \mathrm{C}^{\text {syn/anti }}\right), 22.73\left(\mathrm{CH}_{2}, \mathrm{C}^{\text {syn/anti }}\right), 14.21\left(\mathrm{CH}_{3}, \mathrm{C}^{\text {syn/anti }}\right)$; $m / z(E S I) 630\left(\mathrm{M}^{+}+\mathrm{H}, 43 \%\right)$ and $652\left(\mathrm{M}^{+}+\mathrm{Na}, 100\right)$.

Polyoxyethylene Diazide $(\mathrm{MW}=2000)$ Addition. A solution of $1(5.0 \mathrm{mg}, 15.7 \mu \mathrm{mol})$ and PEG-2000 polyoxyethylene diazide $(\mathrm{MW}=2000)(31.4 \mathrm{mg}, 15.7 \mu \mathrm{mol})$ in $\mathrm{CDCl}_{3}(0.5 \mathrm{~mL}, 0.33 \mathrm{mM})$ was prepared with a J. Young's NMR tube. In situ analysis by NMR spectroscopy indicated formation of a polymeric species. The conversion after 7 days was determined to be $86 \%$ by integration of the starting material versus the polymeric product. GPC analysis indicated the formation of a product of $M_{\mathrm{n}} 13000, M_{\mathrm{w}} 186000$, and PDi 14.25 .

\section{ASSOCIATED CONTENT}

\section{S Supporting Information}

The Supporting Information is available free of charge on the ACS Publications website at DOI: 10.1021/acsomega.8b03634.

General experimental details, synthesis of known compounds, X-ray crystallographic data and NMR spectra for products, conversion/time data, peptide stapling data, and molecular modeling results (PDF)

Empirical details of absorption correction using spherical harmonics and frame scaling in SCALE3 ABSPACK algorithm; list of runs; symmetry information for shelxl refinement (CIF) (CIF) 


\section{AUTHOR INFORMATION}

\section{Corresponding Authors}

*E-mail: spring@ch.cam.ac.uk (D.R.S.).

*E-mail: M.Wills@warwick.ac.uk (M.W.).

ORCID

Richard C. Knighton: 0000-0002-0336-3718

Krishna Sharma: 0000-0001-5220-5823

David R. Spring: 0000-0001-7355-2824

Martin Wills: 0000-0002-1646-2379

\section{Present Address}

${ }^{\S}$ UMR 6521, Université de Bretagne Occidentale, 6, Avenue Victor le Gorgeu, 29200 Brest, France (R.C.K.).

\section{Notes}

The authors declare no competing financial interest. The research data (and/or materials) supporting this publication can be accessed at http://wrap.warwick.ac.uk.

\section{ACKNOWLEDGMENTS}

We acknowledge support from the Engineering and Physical Sciences Research Council (EP/M006670/1; R.C.K. and EP/ P020291/1; D.R.S. \& N.S.R.) and The Royal Society (Wolfson Research Merit Award to DRS). Crystallographic data were collected using instruments purchased through support from Advantage West Midlands (AWM) and the European Regional Development Fund (ERDF) or from the ERC under the European Union's Horizon 2020 research and innovation programme (grant agreement No. 637313). K.S. would like to thank Trinity College, Cambridge Trust, Cambridge Nehru Trust, and the Cambridge Philosophical Society for providing fellowships. We are grateful for the Polymer Characterization RTP (Warwick) and Dan Lester for providing access to the GPC instrument described in the General Experimental Section. Part of this work was performed using the Darwin Supercomputer of the University of Cambridge High Performance Computing Service (http://www.hpc.cam.ac.uk/), provided by Dell Inc.

\section{REFERENCES}

(1) (a) Dommerholt, J.; Rutjes, F. P. J. T.; van Delft, F. L. StrainPromoted 1,3-Dipolar Cycloaddition of Cycloalkynes and Organic Azides. Top. Curr. Chem. 2016, 374, 16. (b) Boudjemeline, M.; McNitt, C. D.; Singleton, T. A.; Popik, V. V.; Kostikov, A. P. $\left[{ }^{18} \mathrm{~F}\right]$ ODIBO: a prosthetic group for bioorthogonal radiolabeling of macromolecules via strain-promoted alkyne-azide cycloaddition. Org. Biomol. Chem. 2018, 16, 363-366. (c) Dovgan, I.; Erb, S.; Hessmann, S.; Ursuegui, S.; Michel, C.; Muller, C.; Chaubet, G.; Cianférani, S.; Wagner, A. Arginine-selective bioconjugation with 4-azidophenyl glyoxal: application to the single and dual functionalisation of native antibodies. Org. Biomol. Chem. 2018, 16, 1305-1311.

(2) (a) Sletten, E. M.; Bertozzi, C. R. Bioorthogonal chemistry: fishing for selectivity in a sea of functionality. Angew. Chem., Int. Ed. 2009, 48, 6974-6998. (b) Palomo, J. M. Click reactions in protein chemistry: from the preparation of semisynthetic enzymes to new click enzymes. Org. Biomol. Chem. 2012, 10, 9309-9318. (c) Gong, Y.; Pan, L. Recent advances in bioorthogonal reactions for site-specific protein labeling and engineering. Tetrahedron Lett. 2015, 56, 21232332. (d) Thirumurugan, P.; Matosiuk, D.; Jowiak, K. Click Chemistry for Drug Development and Diverse Chemical-Biology Applications. Chem. Rev. 2013, 113, 4905-4979. (e) McKay, C. S.; Finn, M. G. Click chemistry in complex mixtures: bioorthogonal bioconjugation. Chem. Biol. 2014, 21, 1075-1101.

(3) (a) Dommerholt, J.; Schmidt, S.; Temming, R.; Hedriks, J. J. A.; Rutjes, F. P. J. T.; van Hest, J. C. M.; Lefeber, D. J.; Friedl, P.; van Delft, F. L. Readily accessible bicyclononynes for bioorthogonal labeling and three-dimensional imaging of living cells. Angew. Chem. Int. Ed. 2010, 49, 9422-9425. (b) Stefanetti, G.; Hu, Q.-Y.; Usera, A.; Robinson, Z.; Allan, M.; Singh, A.; Imase, H.; Cobb, J.; Zhai, H.; Quinn, D.; Lei, M.; Saul, A.; Adamo, R.; MacLennan, C. A.; Micoli, F. Sugar-Protein Connectivity Impacts on the Immunogenicity of SiteSelective Salmonella O-Antigen Glycoconjugate Vaccines. Angew. Chem., Int. Ed. 2015, 54, 13198-13203. (c) Agard, N. J.; Prescher, J. A.; Bertozzi, C. R. A Strain-Promoted $[3+2]$ Azide-Alkyne Cycloaddition for Covalent Modification of Biomolecules in Living Systems. J. Am. Chem. Soc. 2004, 126, 15046-15047. (d) Baskin, J. M.; Prescher, J. A.; Laughlin, S. T.; Agard, N. J.; Chang, P. V.; Miller, I. A.; Lo, A.; Codelli, J. A.; Bertozzi, C. R. Copper-free click chemistry for dynamic in vivo imaging. Proc. Natl. Acad. Sci. USA 2007, 104, 16793-16797. (e) Ning, X.; Guo, J.; Wolfert, M.; Boons, G.-J. Visualizing metabolically labeled glycoconjugates of living cells by copper-free and fast huisgen cycloadditions. Angew. Chem., Int. Ed. 2008, 47, 2253-2255. (f) Debets, M. F.; van Berkel, S. S.; Schoffelen, S.; Rutjes, F. P. J. T.; van Hest, J. C. M.; van Delft, F. L. Azadibenzocyclooctynes for fast and efficient enzyme PEGylation via copper-free $(3+2)$ cycloaddition. Chem. Commun. 2010, 46, 97-99. (g) Jewitt, J. C.; Sletten, E. M.; Bertozzi, C. R. Rapid Cu-Free Click Chemistry with Readily Synthesized Biarylazacyclooctynones. J. Am. Chem. Soc. 2010, 132, 3688-3690. (h) Gordon, C. G.; Mackey, J. L.; Jewett, J. C.; Sletten, E. M.; Houk, K. N.; Bertozzi, C. R. Reactivity of Biarylazacyclooctynones in Copper-Free Click Chemistry. J. Am. Chem. Soc. 2012, 134, 9199-9208.

(4) (a) Wong, H. N. C.; Garrett, P. J.; Sondheimer, F. Unsaturated eight-membered ring compounds. XI. Synthesis of sym-dibenzo-1,5cyclooctadiene-3,7-diyne and sym-dibenzo-1,3,5-cyclooctatrien-7-yne, presumably planar conjugated eight-membered ring compounds. $J$. Am. Chem. Soc. 1974, 96, 5604-5605. (b) Destro, R.; Pilati, T.; Simonetta. Crystal structure of 5,6,11,12-tetradehydrodibenzo[a,e]cyclooctene (sym-dibenzo-1,5-cyclooctadiene-3,7-diyne). M. J. Am. Chem. Soc. 1975, 97, 658-659.

(5) (a) Orita, A.; Hasegawa, D.; Nakano, T.; Otera, J. Double Elimination Protocol for Synthesis of 5,6,11,12-Tetradehydrodibenzo[a,e]cyclooctene. Chem. - Eur J. 2002, 8, 2000-2004. (b) Chaffins, S.; Brettreich, M.; Wudl, F. An Efficient Synthesis of Dibenzocycloocta4a,6a,-diene-5,11-diyne and its Precursors. Synthesis 2002, 11911194. (c) Wong, H. N. C.; Sondheimer, F. Synthesis and reactions of 5,6,11,12-tetradehydrodibenzo[a,e]cyclooctene and 5,6didehydrodibenzo[a,e]cyclooctene. Tetrahedron 1981, 37, 99-109. (d) Dürr, H.; Klauck, G.; Peters, K.; von Schnering, H. G. A Novel Planar Antiaromatic Dibenzo[8]annulene. Angew. Chem., Int. Ed. 1983, 22, 332-333. (e) Man, Y.-M.; Mak, T. C. W.; Wong, H. N. C. Arene synthesis by extrusion reaction. Part 14. Synthesis of benzofused tetraphenylenes and crystal structure of a 4:1 clathrate inclusion compound of dibenzo[b,h]tetraphenylene with p-xylene. J. Org. Chem. 1990, 55, 3214-3221.

(6) Kii, I.; Shiraiski, A.; Hiramatsu, T.; Matsushita, T.; Uekusa, H.; Yoshida, S.; Yamamoto, M.; Kudo, A.; Hagiwara, M.; Hosoya, T. Strain-promoted double-click reaction for chemical modification of azido-biomolecules. Org. Biomol. Chem. 2010, 8, 4051-4055.

(7) (a) Lau, Y. H.; Wu, Y.; Rossmann, M.; Tan, B. X.; de Andrade, P.; Tan, Y. S.; Verma, C.; McKenzie, G. J.; Venkitaraman, A. R.; Hyvönen, M.; Spring, D. R. Double Strain-Promoted Macrocyclization for the Rapid Selection of Cell-Active Stapled Peptides. Angew. Chem., Int. Ed. 2015, 54, 15410-15413. (b) Lau, Y. H.; de Andrade, P.; Wu, Y.; Spring, D. R. Peptide stapling techniques based on different macrocyclisation chemistries. Chem. Soc. Rev. 2015, 44, 91-102. (c) Sharma, K.; Kunciw, D. L.; Xu, W.; Wiedmann, M. M.; Wu, Y.; Sore, H. F.; Galloway, W. R. J. D.; Lau, Y. H.; Itzhaki, L. S.; Spring, D. R. Double-click Stapled Peptides for Inhibiting ProteinProtein Interactions. In Cyclic Peptides: From Bioorganic Synthesis to Applications; Koehnke, J., Naismith, J., van der Donk, W. A., Ed.; The Royal Society of Chemistry: Cambridge, 2018; pp. 164-187.

(8) Hashimoto, C.; Nomura, W.; Narumi, T.; Fujino, M.; Nakahara, T.; Yamamoto, N.; Murakami, T.; Tamamura, H. CXCR4-derived 
synthetic peptides inducing anti-HIV-1 antibodies. Bioorg. Med. Chem. 2013, 21, 6878-6885.

(9) (a) Del Grosso, A.; Galanopoulos, L.-D.; Chiu, C. K. C.; Clarkson, G. J.; O'Connor, P. B.; Wills, M. Strained alkynes derived from 2,2'-dihydroxy-1,1'-biaryls; synthesis and copper-free cycloaddition with azides. Org. Biomol. Chem. 2017, 15, 4517-4521. (b) Mistry, A.; Knighton, R. C.; Forshaw, S.; Dualeh, Z.; Parker, J. S.; Wills, M. Synthesis and cycloaddition reactions of strained alkynes derived from 2,2'-dihydroxy-1,1'-biaryls. Org. Biomol. Chem. 2018, 16, 8965-8975. (c) Harris, T.; Gomes, G. dP.; Ayad, S.; Clark, R. J.; Lobodin, V. V.; Tuscan, M.; Hanson, K.; Alabugin, I. V. Twisted Cycloalkynes and Remote Activation of "Click" Reactivity. Chem 2017, 3, 629-640.

(10) Lindsten, G.; Wennerstroem, O.; Isaksson, R. Chiral biphenyl bis(crown ethers): synthesis and resolution. J. Org. Chem. 1987, 52, 547-554.

(11) Frisch, M. J.; Trucks, G. W.; Schlegel, H. B.; Scuseria, G. E.; Robb, M. A.; Cheeseman, J. R.; Scalmani, G.; Barone, V.; Petersson, G. A.; Nakatsuji, H.; Li, X.; Caricato, M.; Marenich, A. V.; Bloino, J.; Janesko, B. G.; Gomperts, R.; Mennucci, B.; Hratchian, H. P.; Ortiz, J. V.; Izmaylov, A. F.; Sonnenberg, J. L.; Williams, F.; Ding, F.; Lipparini, F.; Egidi, F.; Goings, J.; Peng, B.; Petrone, A.; Henderson, T.; Ranasinghe, D.; Zakrzewski, V. G.; Gao, J.; Rega, N.; Zheng, G.; Liang, W.; Hada, M.; Ehara, M.; Toyota, K.; Fukuda, R.; Hasegawa, J.; Ishida, M.; Nakajima, T.; Honda, Y.; Kitao, O.; Nakai, H.; Vreven, T.; Throssell, K.; Montgomery, Jr., J. A.; Peralta, J. E.; Ogliaro, F.; Bearpark, M. J.; Heyd, J. J.; Brothers, E. N.; Kudin, K. N.; Staroverov, V. N.; Keith, T. A.; Kobayashi, R.; Normand, J.; Raghavachari, K.; Rendell, A. P.; Burant, J. C.; Iyengar, S. S.; Tomasi, J.; Cossi, M.; Millam, J. M.; Klene, M.; Adamo, C.; Cammi, R.; Ochterski, J. W.; Martin, R. L.; Morokuma, K.; Farkas, O.; Foresman, J. B.; Fox, D. J. Gaussian 09, revision D.01, Wallingford, CT, 2013.

(12) (a) Lau, Y. H.; de Andrade, P.; McKenzie, G. J.; Venkitaraman, A. R.; D. R. Spring, D. R. Linear Aliphatic Dialkynes as Alternative Linkers for Double-Click Stapling of p53-Derived Peptides. ChemBioChem 2014, 15, 2680-2683. (b) Lau, Y. H.; de Andrade, P.; Quah, S.-T.; Rossmann, M.; Laraia, L.; Skold, N.; Sum, T. J.; Rowling, P. J. W.; Joseph, T. L.; Verma, C.; Hyvonen, M.; Itzhaki, L. S.; Venkitaraman, A. R.; Brown, C. J.; Lane, D. P.; Spring, D. R. Functionalised staple linkages for modulating the cellular activity of stapled peptides. Chem. Sci. 2014, 5, 1804-1809. 